BUDGET

PERSPECTIVES

2021

PAPER 1

April 2020
THE POTENTIAL COSTS AND DISTRIBUTIONAL EFFECT OF COVID-19 RELATED UNEMPLOYMENT IN IRELAND

KEELAN BEIRNE, KARINA DOORLEY, MARK REGAN, BARRA ROANTREE AND DORA TUDA

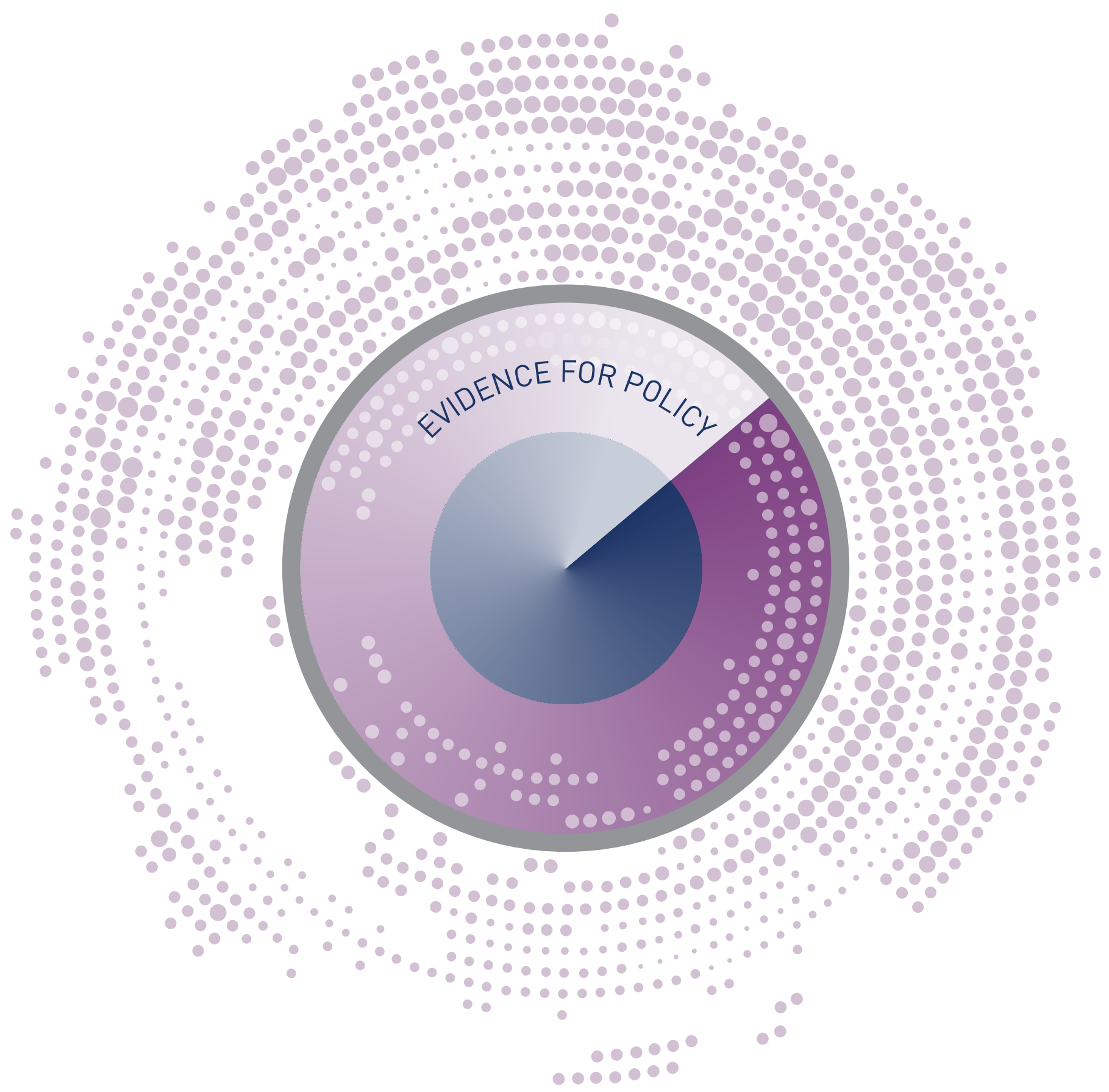




\section{THE POTENTIAL COSTS AND DISTRIBUTIONAL EFFECT OF COVID-19 RELATED UNEMPLOYMENT IN IRELAND}

Keelan Beirne

Karina Doorley

Mark Regan

Barra Roantree

Dora Tuda

April 2020

BUDGET PERSPECTIVES 2021

\section{PAPER 1}

Available to download from www.esri.ie

https://doi.org/10.26504/bp202101

(C) 2020 The Economic and Social Research Institute Whitaker Square, Sir John Rogerson's Quay, Dublin 2

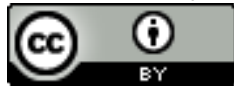

This Open Access work is licensed under a Creative Commons Attribution 4.0 International License (https://creativecommons.org/licenses/by/4.0/), which permits unrestricted use, distribution, and reproduction in any medium, provided the original work is properly credited. 


\section{ABOUT THE ESRI}

The mission of the Economic and Social Research Institute is to advance evidencebased policymaking that supports economic sustainability and social progress in Ireland. ESRI researchers apply the highest standards of academic excellence to challenges facing policymakers, focusing on 12 areas of critical importance to 21st Century Ireland.

The Institute was founded in 1960 by a group of senior civil servants led by $\mathrm{Dr}$ T. K. Whitaker, who identified the need for independent and in-depth research analysis to provide a robust evidence base for policymaking in Ireland.

Since then, the Institute has remained committed to independent research and its work is free of any expressed ideology or political position. The Institute publishes all research reaching the appropriate academic standard, irrespective of its findings or who funds the research.

The quality of its research output is guaranteed by a rigorous peer review process. ESRI researchers are experts in their fields and are committed to producing work that meets the highest academic standards and practices.

The work of the Institute is disseminated widely in books, journal articles and reports. ESRI publications are available to download, free of charge, from its website. Additionally, ESRI staff communicate research findings at regular conferences and seminars.

The ESRI is a company limited by guarantee, answerable to its members and governed by a Council, comprising 14 members who represent a cross-section of ESRI members from academia, civil services, state agencies, businesses and civil society. The Institute receives an annual grant-in-aid from the Department of Public Expenditure and Reform to support the scientific and public interest elements of the Institute's activities; the grant accounted for an average of 30 per cent of the Institute's income over the lifetime of the last Research Strategy. The remaining funding comes from research programmes supported by government departments and agencies, public bodies and competitive research programmes.

Further information is available at www.esri.ie 


\section{THE AUTHORS}

Keelan Beirne is an intern at the ESRI. Karina Doorley is a Senior Research Officer at the ESRI and an Adjunct Associate Professor at TCD. Mark Regan is a Research Analyst at the ESRI and a doctoral candidate at UCD. Barra Roantree is a Research Officer at the ESRI and an Adjunct Assistant Professor at TCD. Dora Tuda is a Research Analyst at the ESRI and a doctoral candidate at TCD.

\section{ACKNOWLEDGEMENTS}

This analysis uses EUROMOD version 12.0+. EUROMOD is maintained, developed and managed by the Institute for Social and Economic Research (ISER) at the University of Essex, in collaboration with national teams from the EU Member States. We are indebted to the many people who have contributed to the development of EUROMOD. The process of extending and updating EUROMOD is financially supported by the European Union Programme for Employment and Social Innovation 'Easi' (2014-2020). The results and their interpretation are the authors' responsibility. Funding for the Tax, Welfare and Pensions Research Programme (supported by the Departments of Employment Affairs and Social Protection; Public Expenditure and Reform; Health, Children and Youth Affairs; and Finance) is gratefully acknowledged.

This paper has been accepted for publication by the Institute, which does not itself take institutional policy positions. The paper has been peer reviewed prior to publication. The authors are solely responsible for the content and the views expressed. 


\section{TABLE OF CONTENTS}

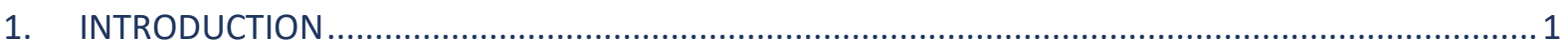

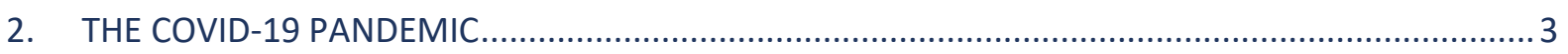

3. SIMULATING THE EFFECT OF COVID-19 ON INCOME DISTRIBUTION AND THE EXCHEQUER......... 4

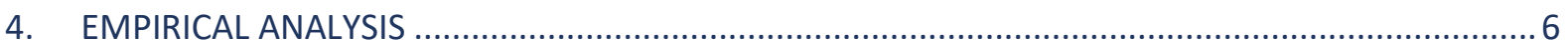

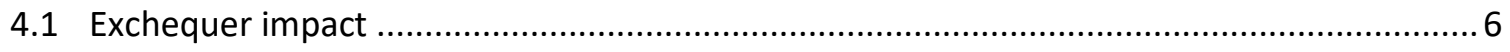

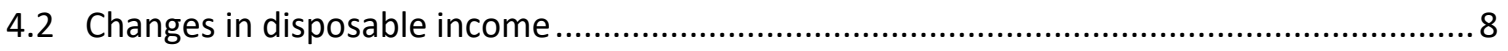

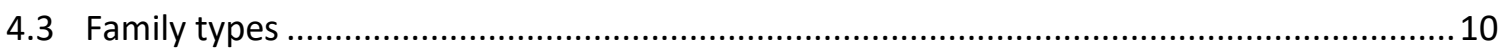

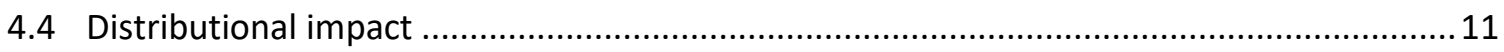

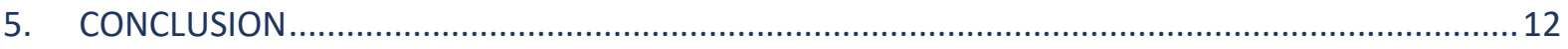

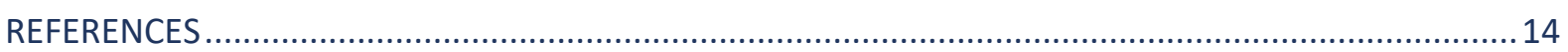

\section{LIST OF TABLES}

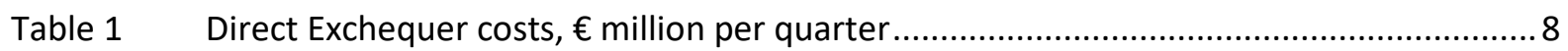

Table 2 Average change in disposable income, by family type, due to unemployment shock ....10

Table A.1 Assumed distribution of unemployment shock, by sector.............................................15

Table B.1 Direct Exchequer costs, € million per quarter ('low' unemployment shock)..................16

Table B.2 Average change in disposable income, by family type ('low' unemployment shock) .....16

Table C.1 Direct Exchequer costs, $€$ million per quarter ('high' unemployment shock)..................18

Table C.2 Average change in disposable income, by family type ('high' unemployment shock) ....18

\section{LIST OF FIGURES}

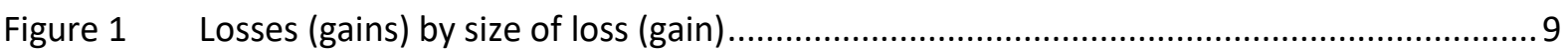

Figure 2 The distributional impact of a pandemic-related unemployment shock.........................11

Figure B.1 Losses (gains) by size of loss (gain), under 'low' unemployment shock .........................17

Figure B.2 Distributional effect of 'low' unemployment shock ......................................................17

Figure C.1 Losses (gains) by size of loss (gain), under 'high' unemployment shock ........................19

Figure C.2 Distributional effect of 'high' unemployment shock.................................................. 19 


\title{
THE POTENTIAL COSTS AND DISTRIBUTIONAL EFFECT OF COVID-19 RELATED UNEMPLOYMENT IN IRELAND
}

\begin{abstract}
This paper simulates the impact that Covid-19 related job losses will have on family incomes and the public finances. It finds that in the central 'medium' unemployment scenario of 600,000 job losses, around 400,000 families will see their disposable income fall by more than 20 per cent in the absence of policy changes, with proportionately larger losses for those in higher income families. Measures announced by the Government - notably the flat-rate Pandemic Unemployment Payment of $€ 350$ per week - reduce the numbers exposed to such extreme losses by about a third, but at significant cost to the Exchequer. The paper also finds that the additional cost of the Government's Temporary Wage Subsidy Scheme may be minimal, in part because its current design is less generous to lower earners than the Pandemic Unemployment Payment they would receive if laid off.
\end{abstract}

\section{INTRODUCTION}

The Covid-19 pandemic has had wide ranging consequences for almost every area of life in the countries that it has affected. In addition to the direct health effects of the virus, serious economic disruption has been caused by the public health measures necessary to contain the spread of the virus. The OECD estimates that three months of shutdown could reduce annual GDP growth by between 4-6 percentage points in affected countries (OECD, 2020). In Ireland, recent ESRI estimates indicate that a 12-week shutdown could reduce consumption over the period by 25 per cent and shrink the economy by 7.1 per cent in 2020 (ESRI, 2020) while the Central Bank of Ireland estimates that GDP could decline by 8.3 per cent in 2020 (Central Bank of Ireland, 2020).

As a result of the public health measures taken to contain the virus in Ireland and abroad, many businesses have reduced the size of their workforce or, indeed, closed down altogether. This has resulted in a sudden and significant increase in unemployment. The Irish government has responded to this employment shock by introducing a range of new income supports and wage subsidies. First, a 12-week non means-tested unemployment support - the 'Covid-19 Pandemic Unemployment Payment' (PUP) - was made available to all employees and the self-employed who lost their jobs on or after 13 March at a rate of $€ 203$ per week, 
increased to $€ 350$ per week from 24 March. ${ }^{1}$ Second, the waiting period for Illness Benefit was abolished for those who contract the virus and/or are required to selfisolate and the rate of this benefit increased to match that of the PUP. ${ }^{2}$ Third, fuel allowance was increased by extending the winter fuel season by four weeks. Fourth, the government also announced a Temporary Wage Subsidy Scheme (TWSS) that will subsidise up to 70 per cent of the net wages of employees whose employers are severely affected by the pandemic, up to a maximum of $€ 410$ per week. ${ }^{3}$ The employer can make an additional payment to employees (up to a maximum) that is subject to a reduced rate of employer PRSI. Finally, for employees in the childcare sector, the Department of Children and Youth Affairs (DCYA) announced that it would subsidise the remaining 30 per cent of the wage bill up to a maximum of $€ 350$ per week. Childcare providers will also receive an additional payment from the Department of 15 per cent of their staff costs to use for overheads. ${ }^{4}$

Using EUROMOD, the European tax-benefit model (Sutherland and Figari, 2013), we provide a first estimate of how the projected changes in unemployment due to the Covid-19 pandemic affect family income in the three months following the unemployment shock. We also quantify the Exchequer impact of the increase in unemployment and the introduction of discretionary policy measures, taking the full interaction of these measures with the existing tax-benefit system into account.

A number of important assumptions underlie this analysis. Firstly, we consider only the impact of job losses and not any reductions in working hours, earnings or other income arising from the Covid-19 pandemic. That is, we take estimates of the unemployment shock by sector and assume that those not directly affected by the shock do not see any change in their hours, earnings or other income. Second, we consider the short-run impact of the shock, assuming behaviour does not change, and report results on a quarterly basis. This is because there is little indication of how long the shutdown is likely to last or the path of the recovery. Thirdly, while our estimate of the impact of the Covid-19 pandemic on incomes and the Exchequer takes account of the reduction in labour income and its interaction with existing and new direct tax-benefit policies (including government wage subsidies), it does not take into account indirect taxation or general government expenditure on health, education or other public services. In terms of changes to the tax-benefit system, we model the introduction of the Pandemic Unemployment Payment and the Temporary Wage Subsidy Scheme (excluding the DCYA top-up) along with an

https://www.gov.ie/en/service/be74d3-covid-19-pandemic-unemployment-payment https://www.gov.ie/en/service/df55ae-how-to-apply-for-illness-benefit-for-covid-19-absences https://revenue.ie/en/corporate/communications/covid19/temporary-covid-19-wage-subsidy-scheme.aspx https://www.gov.ie/en/publication/17507b-information-on-covid-19-measures-for-providers-and-staff-of-early-le/ 
increase to the Fuel Allowance. ${ }^{5}$ Aside from these discretionary policy changes, we assume no further changes to the 2020 tax and benefit system.

\section{THE COVID-19 PANDEMIC}

By 5 April 2020, there were 1,133,758 confirmed cases of the virus worldwide in 206 countries, with 62,784 confirmed deaths. Almost three-quarters of reported deaths have occurred in Europe, which has become the epicentre of the crisis (WHO, 2020a). The US is quickly joining Europe at the centre of the outbreak with 163,199 confirmed cases, the highest number of any country. As of 5 April, Ireland has 4,994 confirmed cases, with 158 deaths resulting from Covid-19 recorded in the country (Department of Health, 2020a).

On 29 February, the first case of Covid-19 was confirmed in Ireland. On 12 March the Irish Government made the decision to close schools, childcare facilities, universities and other public buildings until 29 March, resulting in job losses concentrated in the early childcare sector (Department of Health, 2020b). Mass gatherings were also cancelled. On $15 \mathrm{March}$, the Government instructed pubs and bars to close until at least March 29, resulting in large loss of employment in the hospitality sector. The PUP was announced on the same day at a rate of $€ 203$ per week, increased to $€ 350$ per week following an announcement on 24 March. Illness Benefit for Covid-19 related absences was also increased to $€ 350$ per week and the six-day waiting period was abolished.

On 18 March the retail banks in operation in Ireland announced a series of measures to support customers, including a payment break of up to three months. On the following day the Minister for Employment Affairs and Social Protection introduced the Employer Refund Scheme by which employees could remain on company payrolls while receiving the amount of the Covid-19 Support Payment, the cost of which would be reimbursed to relevant businesses. This scheme was superseded by the Temporary Wage Subsidy Scheme (TWSS) from 26 March, allowing employers to claim subsidies of up to $€ 410$ per week for eligible employees they retain on payroll. The scheme operates by paying 70 per cent of employees' average net pay in January and February subject to a cap of €410 per week. However, a lower subsidy of $€ 350$ per week is paid to anyone whose average net pay was more than $€ 586$ per week, while those whose average net pay was more than $€ 960$ per week receive no subsidy. Employers can make an additional payment to eligible employees up to a maximum of the difference between the

We do not include the increase in Illness Benefit claims in our analysis as doing so would require modelling the infection curve for the next three months. We also exclude the DCYA top-up as our data are not detailed enough to identify this sector. 
subsidy and their average net pay, which is subject to a reduced 0.5 per cent rate of employer PRSI. Both the subsidy and any additional payment are subject to income tax and USC, though these will not be deducted through payroll.

An extended range of measures was announced on 27 March to combat the spread of the virus, with the Government urging all non-essential businesses to close, including construction sites unrelated to pandemic efforts, while stating individuals should only leave their home when necessary and those over 70 years of age should not leave their homes at all (DEASP, 2020).

\section{SIMULATING THE EFFECT OF COVID-19 ON INCOME DISTRIBUTION AND THE EXCHEQUER}

The pandemic and subsequent policy response has led to an unprecedented rise in unemployment, with the Live Register (including PUP and TWSS applications) showing an increase of 330,734 from February to March (CSO, 2020b). These figures suggest a 12 percentage point rise in unemployment over this period, which would more than triple the headline figure from 4.8 per cent to 16.8 per cent with more job losses expected in the coming weeks. ${ }^{6}$ Eichenbaum et al. (2020) show that quarantine measures can cause severe recessions, while many leading commentators and policymakers are predicting a severe and possibly prolonged global downturn (Baldwin and di Mauro, 2020). At the time of writing, weekly payments of the Covid-19 PUP exceeded 500,000 while 39,000 employers had registered with the Revenue Commissioners for the TWSS.

Job losses have not and will not be evenly distributed across industry or occupation. ${ }^{7}$ Heavier job losses are projected to be experienced in the retail, accommodation and food service activities.

To simulate the effect of the Covid-19 unemployment shock, we use the 2017 European Union Statistics on Income and Living Conditions (EU-SILC). The survey contains detailed information on the incomes and labour market participation of over 5,000 households. These data are uprated to be representative of the 2020 population in terms of income distribution and linked to EUROMOD, the EU tax-

Based on applying trends for the Live Register to February unemployment numbers, and assuming all individuals availing of the PUP (but not TWSS) are unemployed. This is consistent with the CSO's methods for calculating unemployment. If PUP recipients are not considered unemployed but rather, temporarily outside the labour force, this method may overstate the unemployment rate (Central Bank of Ireland, 2020).

$7 \quad$ They are also likely to be unevenly distributed across gender and age cohort but we do not account for this in these initial simulations as limited data are currently available. 
benefit model. ${ }^{8}$ EUROMOD models the direct tax and benefit system in Ireland for 2020.

We consider three scenarios for the projected increase in unemployment as a result of the Covid-19 pandemic. In our central 'medium' scenario (which we focus on in the following section), we simulate the effect of around 600,000 individuals losing their jobs. ${ }^{9}$ We also provide estimates for a 'low' and 'high' scenario in the Appendix, where job losses are assumed to amount to roughly 400,000 and 800,000 respectively. These are in addition to those already unemployed, estimated by the CSO to be 120,000 in February 2020 (CSO, 2020a). In each case, job losses are simulated to be more concentrated in the sectors projected to be most at risk ${ }^{10}$ and are assumed to last for the full quarter we study. ${ }^{11}$ We estimate the effect of this quarter of economic disruption on incomes and on government revenue from direct taxation and social welfare expenditure.

Given these unemployment scenarios, we also consider four policy scenarios:

A. No discretionary policy response: Unemployment rises sharply and persists for three months. The tax-benefit system applied to this scenario is that in place in February 2020, i.e. it does not account for any pandemic related discretionary policy changes. Comparing this scenario to the baseline (with no unemployment shock) gives the scale of the income shock in the absence of any changes to the tax and benefit system.

B. PUP: Unemployment rises as in Scenario (A). The Pandemic Unemployment Payment (PUP) is available for three months to all those who lose their jobs as a result of the pandemic, with anyone previously claiming Working Families Payment eligible to continue receiving the benefit (the amount is assessed at their new level of income). Those who are better off on contributory Jobseekers Benefit than PUP claim the former. An extra month of fuel allowance is also paid to recipients of this means-tested payment.

8 We uprate monetary variables to their 2019 levels using a range of of indices (such as CPI, GDP growth etc). Such indices are not available for 2020 so, given the current levels of uncertainty, we assume no growth between 2019 and 2020.

9 We simulate the effect of job losses among employees and self-employed who report working at least nine months in the last year and who we assume qualify for contributory Jobseekers Benefit (no information is available in the EU-SILC data on the number of PRSI contributions in the relevant tax year). The weighted number of individuals who we simulate to lose their jobs in the medium scenario is 618,000 , corresponding to $70-80$ per cent in high risk sectors, 20-60 per cent in medium risk sectors and 5 per cent in low risk sectors (see also Table A.1 in Appendix A).

10 See Table A.1 in Appendix A for a summary of how job losses are distributed in each sector. Simulated job losses are random within these sectors so our results are associated with a degree of uncertainty. If, within sectors, job losses are actually more concentrated among lower income individuals, we will overstate the loss in direct tax revenues, especially income tax and USC.

11 The main policy instruments are set to be in place for 12 weeks. As the EUROMOD model works with monthly income, we approximate this to three months. 
C. PUP + TWSS: In this scenario, we model the Temporary Wage Subsidy Scheme (TWSS) as being fully in place in addition to the PUP. ${ }^{12}$ We assume that some of those employees eligible for the TWSS who lose their jobs in scenarios $A$ and $B$ are instead retained by their employer. Unemployment rises by 300,000 in each unemployment scenario with the remainder of shocked workers moving onto the TWSS. ${ }^{13}$ Employers do not top up the salaries of workers benefitting from the TWSS.

D. PUP + TWSS + top-up: This scenario is similar to Scenario C except that employers top up the salaries of those employees benefitting from the TWSS to the maximum amount allowed (100 per cent of their previous net earnings). The top-up is subject to income tax, USC and a reduced ( 0.5 per cent) rate of employer PRSI but not subject to employee PRSI.

\section{EMPIRICAL ANALYSIS}

\subsection{Exchequer impact}

Table 1 shows the estimated Exchequer cost per quarter of each of the four policy scenarios for a medium unemployment shock (results for the 'low' and 'high' unemployment scenarios can be found in Appendices $B$ and $C$ respectively).

The estimated Exchequer cost for Scenario $A$ (no policy change) is $€ 4.1$ billion per quarter. A large part of this figure is made up of a reduction in income tax receipts of $€ 1.3$ billion, resulting from a $€ 6.4$ billion reduction in market income. There is also a reduction of (employee, employer and self-employed) PRSI receipts of $€ 0.8$ billion, an increase in spending on means-tested welfare of $€ 70$ million and an increase in non means-tested welfare expenditure of $€ 1.9$ billion.

In Scenario B, which adds the PUP and increased fuel allowance, the estimated cost to the Exchequer rises to $€ 4.9$ billion per quarter. This is driven by a large increase in non means-tested welfare expenditure (from $€ 1.9$ billion to $€ 2.8$ billion) arising from the granting of PUP rather than standard Jobseeker's Benefit to most claimants. This is somewhat offset by a smaller reduction in direct tax revenue (as the PUP is subject to income tax) but there is also a small increase in means tested

12 Guidance from the Revenue Commissioners states that while employers will receive a subsidy of €410 per eligible employee in the transition period, they are required to "hold the excess of the subsidy payment received over the amount of subsidy actually to each employee' and that 'this excess amount will be taken into account by Revenue when paying future subsidy payments to employer or will be repaid directly to Revenue'. See https://revenue.ie/en/corporate/communications/covid19/temporary-covid-19-wage-subsidyscheme.aspx.

13 By 27 March, the day after the wage subsidy scheme commenced, there had been 323,000 applications for the Pandemic Unemployment Payment, excluding duplicates. See https://www.gov.ie/en/news/728c73-update-onpayments-awarded-for-covid-19-pandemic-unemployment-paymen/. 
welfare expenditure (from $€ 70$ million to $€ 80$ million), due to the extension to fuel allowance and the ability for those in receipt of PUP to retain any eligibility for Working Families Payment at their new level of income.

Scenario C introduces the TWSS and simulates the effect of 300,000 remaining unemployed and the remainder returning to their employers' payroll under this scheme. ${ }^{14}$ This scenario sees lower income tax receipts compared to Scenario B as the subsidy is paid as a proportion of average net wages and not all employees are entitled to the $€ 350$ or $€ 410$ payment. ${ }^{15}$ There is a sizable decrease (from $€ 2.8$ billion to $€ 1.4$ billion) in additional non means-tested welfare expenditure coupled with expenditure of $€ 1.2$ billion on the TWSS. The net Exchequer impact of Scenario $C$ is slightly lower ( $€ 4.8$ billion) than that of Scenario B (- $€ 4.9$ billion).

In Scenario D, employers are assumed to top-up the wages of their employees beyond the wage subsidy to the maximum allowed level. This results in higher income tax receipts (the shortfall moving from $€ 1.2$ billion to $€ 1.1$ billion). It also results in a slightly smaller rise in means-tested social welfare expenditure. The net Exchequer cost falls from - $€ 4.8$ billion to $-€ 4.5$ billion.

Appendix B and C provide the Exchequer cost for the 'low' and 'high' unemployment scenarios. The estimates appear to be reasonably scalable. For example, in Scenario D, the next Exchequer impact of around 400,000; 600,000 or 800,000 job losses is $€ 3.2$ billion, $€ 4.5$ billion or $€ 5.8$ billion, respectively. Extrapolating from these three scenarios, we estimate that a rise in unemployment could reduce direct tax revenues and increase welfare spending by around $€ 800$ million per quarter for every 100,000 individuals that lose their job.

14 Self-employed individuals are not eligible for the scheme while not all employees will qualify for the subsidy because they have earnings above the maximum eligible amount.

15 Our simulations suggest a large degree of bunching at the lower wage subsidy rate of €350 with many employees receiving less than this. This points to potentially adverse incentives for employees to stay on payroll rather than claiming the PUP in addition to other income supports (such as rent supplement). 


\begin{tabular}{|c|c|c|c|c|}
\hline & $\mathbf{A}$ & B & C & D \\
\hline Change in market income & $-6,411$ & $-6,411$ & $-5,247$ & $-4,456$ \\
\hline Change in personal income tax revenue & $-1,342$ & $-1,152$ & $-1,298$ & $-1,117$ \\
\hline Change in employee SIC revenue & -229 & -229 & -229 & -229 \\
\hline Change in self-employed SIC revenue & -48 & -48 & -48 & -48 \\
\hline Change in employer SIC revenue & -556 & -556 & -556 & -552 \\
\hline Change in means-tested welfare expenditure & 70 & 80 & 119 & 60 \\
\hline Change in non means-tested welfare expenditure & 1,850 & 2,839 & 1,360 & 1,359 \\
\hline Cost of temporary wage subsidy & 0 & 0 & 1,173 & 1,173 \\
\hline Net Exchequer impact & $-4,095$ & $-4,904$ & $-4,784$ & $-4,538$ \\
\hline
\end{tabular}

Source: $\quad$ Own calculations using EUROMOD linked to 2017 EU-SILC data uprated to 2020 terms.

Notes: $\quad$ Calculations show the estimated quarterly cost of medium unemployment shock under four scenarios: $A-$ no policy response; B - introduction of PUP and extension of fuel allowance; C - as B but half retained in employment through TWSS; D - as C but with additional payments by employers to maximum allowed under TWSS.

\subsection{Changes in disposable income}

We first consider the proportion of families in Ireland that the simulated unemployment shock affects in each of our policy scenarios. ${ }^{16}$ In Scenario A, around 1.5 million families see no change to their disposable income after the unemployment shock. This figure falls to 1.1 million in Scenario B and 1.2 million in Scenarios $C$ and $D$. Figure 1 shows the distribution of losses (and gains) for families who experience income changes. In Scenario A (no policy response) 560,000 families see their disposable income fall while a small number $(20,000)$ see theirs rise. Families who gain are mostly those for whom Jobseekers Benefit (including increases for qualified adults and children) exceed their after tax earnings, with gains short-lived and of a relatively small magnitude. ${ }^{17}$ Of those who see declines in their disposable income 62,000 lose by less than 5 per cent of disposable income; 94,000 lose by $5-20$ per cent of disposable income; 188,000 lose by $20-40$ per cent of disposable income; 145,000 lose by $40-60$ per cent of disposable income; and 69,000 lose by more than 60 per cent of disposable income.

16 By family, we mean tax unit, defined as single; married or cohabiting adults and any dependent children. See Appendices B and C for estimates of the other (low and high) simulated employment shocks.

17 Due to the nature of Jobseekers Benefit, this gain only lasts for the duration of payment (nine months maximum). For the PUP, this gain is even shorter-lived (12 weeks). 


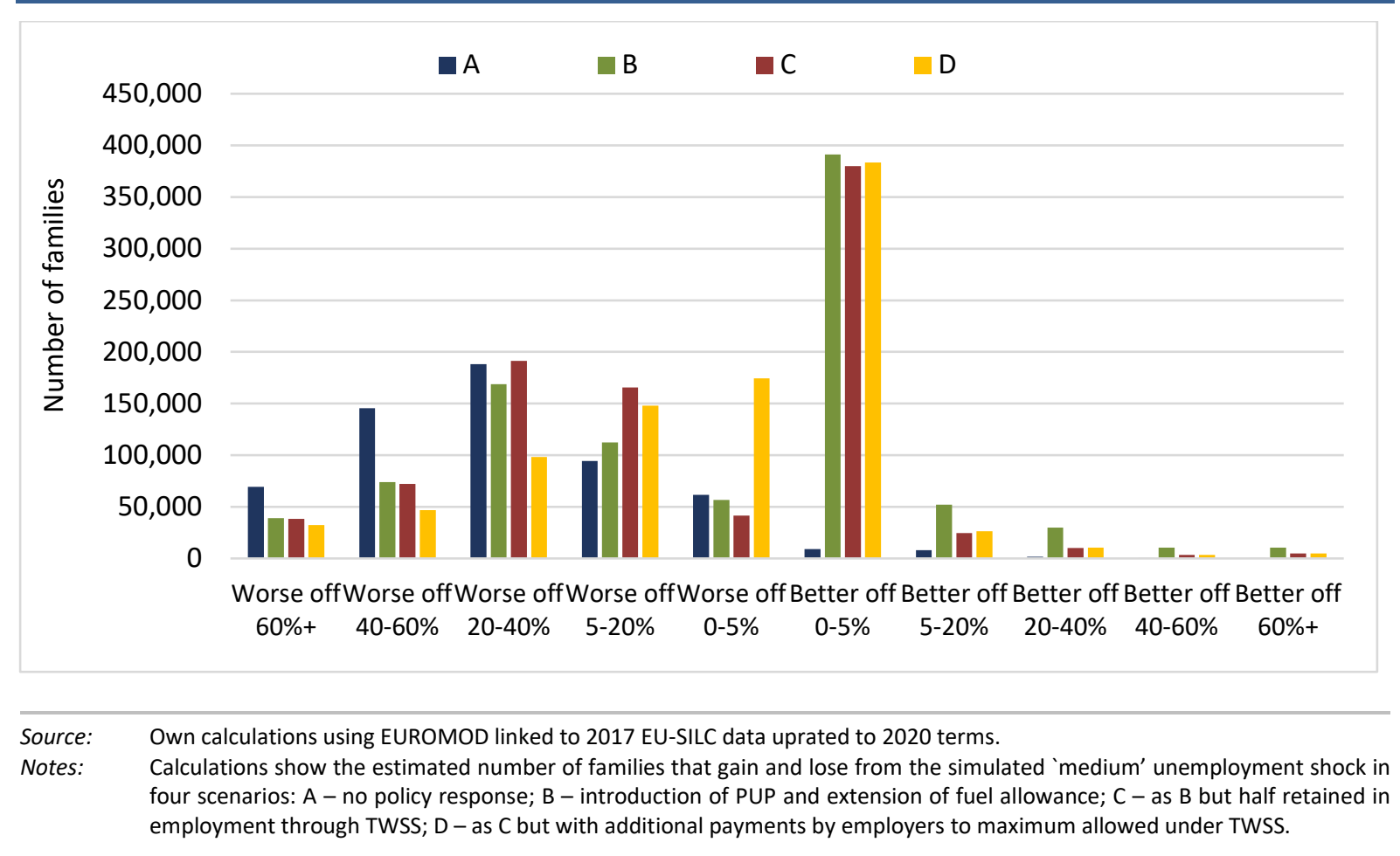

The introduction of PUP and extension of the fuel allowance (Scenario B) results in significant mitigation of these losses. The number of families who see a reduction in their disposable income falls by 110,000 to 450,000 . Significantly fewer families experience losses greater than 20 per cent of disposable income: around 280,000 compared to 400,000 in Scenario A. This is largely the result of the $€ 350$ flat-rate PUP, which is more generous for most newly unemployed individuals than the Jobseekers Benefit they would otherwise get. Indeed, the income from the PUP leaves some low-income families financially better off than they were in work. ${ }^{18}$ In addition, the extension of the fuel allowance season benefits a large number of retirees whose incomes are otherwise unaffected by the rise in unemployment, leaving more than 300,000 such retired families financially better off, mostly by between 0 and 5 per cent of disposable income.

Compared to Scenario B, the TWSS without any employer top-up (Scenario C) leaves more families worse off and fewer better off, with most of the increase in the 5-20 per cent and 20-40 per cent worse-off bands. This is because many of those eligible for the TWSS receive less than the flat-rate €350 PUP without additional payments from employers. Simulating the effect of these additional payments (Scenario D) slightly reduces the number of families who are worse off (from 510,000 to 500,000 ) while significantly reducing the share of families who 
lose by more than 20 per cent of their disposable income, from 300,000 to around 175,000 . However, a sizeable minority (around one-fifth) still see their incomes fall by more than 40 per cent.

\subsection{Family types}

Table 2 shows the estimated average change in disposable income by family type across each of the policy scenarios modelled. We distinguish between singles and couples, those with and without children and those of working and retirement age. In Scenario A (no policy response), working age couples with children are estimated to lose by an average of $\mathbf{1 5 . 9}$ per cent of disposable income, closely followed by working age singles without children and working age couples with children at 15.1 per cent and 14.4 per cent respectively. On average, working age lone parents and retirees lose by the least (less than 5 per cent of disposable income for each group) due to the fact that they are less likely to be in work and more likely to receive their income in the form of benefits before the unemployment shock.

The introduction of PUP (Scenario B) almost halves the average loss among working age singles without children, from 15.1 per cent to 8.7 per cent, while reducing that for couples with and without children by around one-fifth. In addition, it reduces the average loss for lone parents to less than 1 per cent. Similarly, the extension of the winter fuel payment reduces the average loss for retirees to negligible levels.

TABLE 2 AVERAGE CHANGE IN DISPOSABLE INCOME, BY FAMILY TYPE, DUE TO UNEMPLOYMENT SHOCK

\begin{tabular}{|c|c|c|c|c|c|c|}
\hline & $\%$ of tax units & A \% & B \% & C \% & D \% \\
\hline \multicolumn{2}{|c|}{ Working age single without children } & 28 & -15.1 & -8.7 & -10.2 & -7.0 \\
\hline \multicolumn{2}{|c|}{ Working age lone parent } & 8 & -4.9 & -0.6 & -3.0 & -1.6 \\
\hline \multicolumn{2}{|c|}{ Working age couple without children } & 15 & -14.4 & -10.7 & -11.4 & -8.4 \\
\hline \multicolumn{2}{|c|}{ Working age couple with children } & 28 & -15.9 & -12.7 & -13.1 & -10.2 \\
\hline \multicolumn{2}{|c|}{ Single retirement age } & 12 & -2.2 & 0.0 & -0.2 & -0.1 \\
\hline \multicolumn{2}{|c|}{ Couple retirement age } & 9 & -3.6 & -0.9 & -1.2 & -0.9 \\
\hline Source: & \multirow{2}{*}{\multicolumn{6}{|c|}{$\begin{array}{l}\text { Own calculations using EUROMOD linked to } 2017 \text { EU-SILC data uprated to } 2020 \text { terms. } \\
\text { Working age is defined as } 18-65 \text {. Children are aged under 18. Retirement age is } 66+\text {. Calculations show the average change in } \\
\text { disposable income for different types of tax-unit due to a 'medium' unemployment shock under four scenarios: A - no policy } \\
\text { response; B - introduction of PUP and extension of fuel allowance; C - as B but half retained in employment through TWSS; } \\
\text { D- as C but with additional payments by employers to maximum allowed under TWSS. }\end{array}$}} \\
\hline Notes: & & & & & & \\
\hline
\end{tabular}

Average losses are higher across all family types in Scenario $C$ because many eligible for the TWSS receive less than they would if they were made unemployed and received PUP. This effect is offset if the employer makes the maximum additional top-up payment allowed under the scheme (Policy Scenario D), with 
average losses for those of working age reduced by between 1 and 3 percentage points.

\subsection{Distributional impact}

Figure 2 shows the distributional effect of the unemployment shock under each of the four policy scenarios, with families grouped into quintiles of disposable income adjusted ('equivalised') ${ }^{19}$ for household size. ${ }^{20}$ In Scenario A, the unemployment shock leads to a reduction in disposable income of around 2 per cent in households in the bottom income quintile. The proportionate loss rises to 3 per cent for households located in the second income quintile. Households in the top three income quintiles experience the largest proportionate loss in disposable income at 11-18 per cent on average. This reflects the cushioning provided by the existing tax-benefit system which replaces a larger proportion of low-income families' income than those further up the income distribution. Additionally, lower income families are less likely to contain someone in work and so be affected by the shock.

FIGURE 2 THE DISTRIBUTIONAL IMPACT OF A PANDEMIC-RELATED UNEMPLOYMENT SHOCK

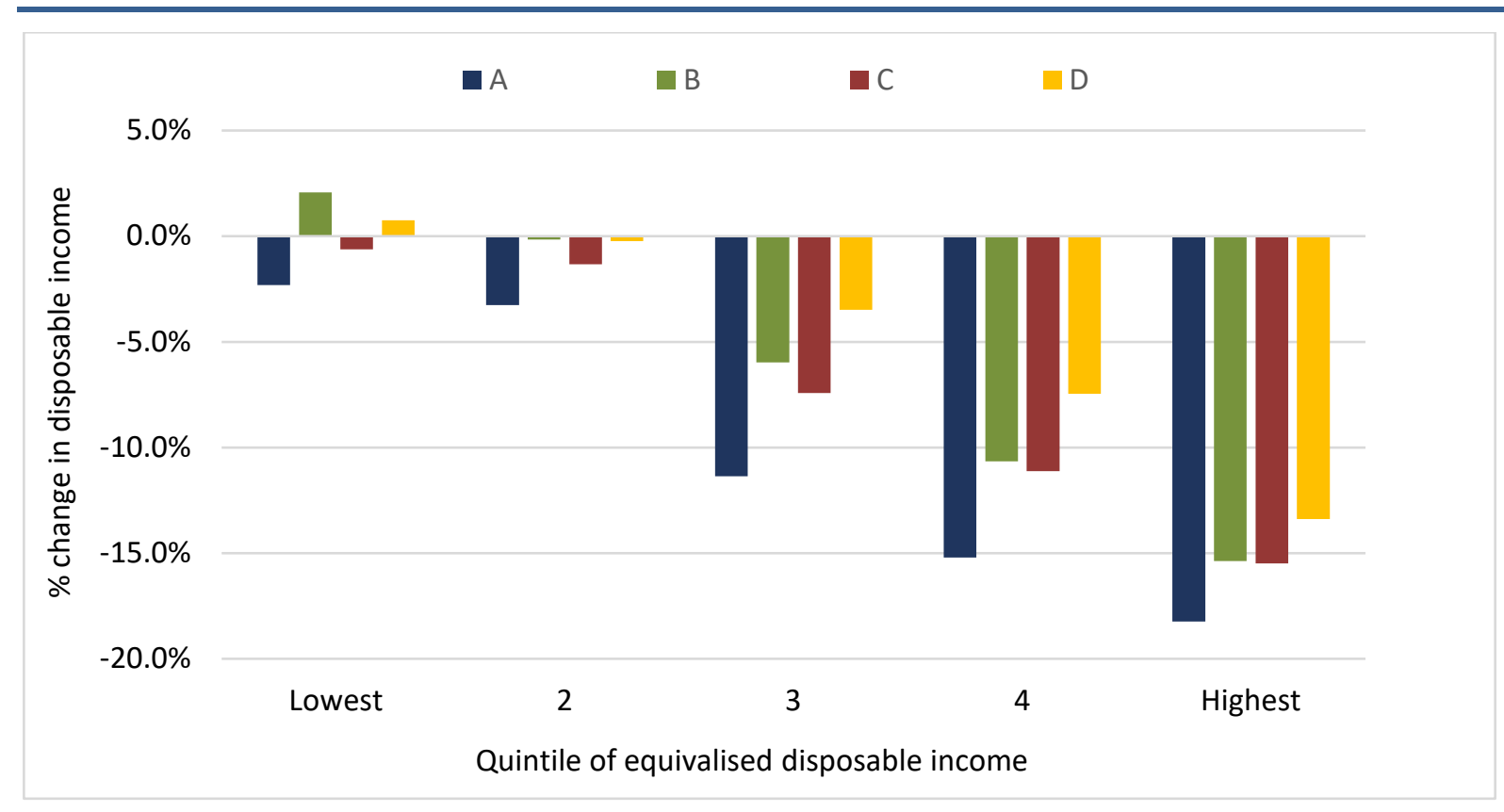

Source: $\quad$ Own calculations using EUROMOD linked to 2017 EU-SILC data uprated to 2020 terms.

Notes: Calculations show the average change in disposable income by quintile of equivalised disposable income of a 'medium' unemployment shock for three months under four scenarios: A - no policy response; B - introduction of PUP and extension of fuel allowance; $C$ - as B but half retained in employment through TWSS; D - as C but with additional payments by employers to maximum allowed under TWSS.

19 We use the CSO national equivalence scales which assign a weight of 1 for the first adult in a family, 0.66 for any additional adults and 0.33 for any children.

20 Percentage changes are not comparable to those reported in Figure 1 as Figure 1 only shows the distribution of (gains) losses for those whose income changes. 
Introducing the PUP and fuel allowance extension in Scenario B results in the bottom two income quintiles being - on average - largely insulated from losses. The bottom quintile actually gains slightly as a percentage of disposable income as many of them were earning less than the flat rate provided by the PUP before they became unemployed. The measures introduced in Scenario B also cushion income losses for those higher up the income distribution, although those in the top quintile still lose 15 per cent of their disposable income on average.

The distributional effect of the unemployment shock does not change substantially in moving from Scenario $B$ to Scenario $C$, although the small average gains for the bottom quintile become small average losses. Modelling the effect of employer top-ups in Scenario D does however change the distributional picture, particularly benefiting those located in the middle of the distribution. Losses in quintiles 3 and 4 drop to 4 per cent and 8 per cent of disposable income, respectively. The top quintile still sees a large decrease in disposable income, however, as many of those in this quintile are not eligible for the TWSS due to their high earnings.

\section{CONCLUSION}

This analysis provides an initial estimate of the possible impact of Covid-19 on the public finances and the distribution of income. Making use of the best available projections for the unemployment shock induced by the response to the Covid-19 pandemic, we estimate that a rise in unemployment will reduce direct tax revenues and increase welfare spending by around $€ 800$ million per quarter for every 100,000 individuals that lose their job. This is in addition to any impact on other tax revenues (notably indirect taxes from reduced expenditure) or public spending. This also takes no account of the potential effect of reduced hours and incomes for those who maintain their employment.

We estimate that before accounting for the Government's policy response, around 560,000 families will be financially worse off in our medium unemployment scenario where roughly 600,000 individuals lose their job. Most of these $-400,000$ - would lose by more than 20 per cent of their disposable income. Accounting for the measures announced by the Government, this figure falls to between 200,000 and 300,000 depending on how many are retained in work through the TWSS and whether employers make additional payments to eligible employees. While most instead see reductions of less than 20 per cent of their disposable income, some low-earning working age families may be financially better off in the short-run. This is because the level of PUP exceeds their income from work and they are allowed to retain eligibility for Working Families Payment. Although work incentive effects are of little importance while public health measures are in place, our simulations 
suggest careful consideration should be given to how these supports will withdrawn in the future as public health measures are lifted and the economy begins to recover.

We estimate that the pandemic unemployment shock will result in higher income families seeing larger proportionate falls in their incomes than lower income families. Families in the lower two-fifths of the income distribution are, on average, insulated from income losses. This is due to the cushioning performed by both the pre-existing tax-benefit system and the new policy measures, as well as the fact that low income families are less likely to contain someone in work.

Our results also show that, of the policy measures announced by the Government, the PUP does most to cushion family incomes, but at significant cost (almost $€ 1$ billion per quarter for the medium simulated unemployment shock). The extension of the fuel allowance season also benefits a large number of retirees. Notably, the TWSS adds little to the cost of the policy response as most employees will receive no more under this scheme than they would through PUP and some will receive less. This feature of the scheme may, however, incentivise employees to seek unemployment or encourage firms to lay-off higher earners, for whom a lower or zero subsidy is paid. A central aim of the TWSS is for employers to retain links with employees for when business picks up after the crisis. Ensuring that both employees and employers have an incentive to take up this payment is important to ensuring it achieves this objective.

The purpose of this research is to provide timely information to policymakers at a time when both the labour market and labour market policy are rapidly evolving. Updates to this analysis may be provided as more data become available. Further research will investigate options for revenue raising and stabilising income inequality and poverty in the aftermath of the Covid-19 pandemic. 


\section{REFERENCES}

Baldwin, R. and B. di Mauro (2020). Mitigating the COVID Economic Crisis: Act Fast and Do Whatever It Takes.

Central Bank of Ireland (2020). Quarterly Bulletin 2: April 2020.

Central Statistics Office (2020a). 'CSO statistical release, 03 March 2020, 11am'. https://www.cso.ie/en/releasesandpublications/er/mue/monthlyunemploymen tfebruary2020/ (accessed 2/4/2020).

Central Statistics Office (2020b). 'CSO statistical release, 02 April 2020, 11am'. https://www.cso.ie/en/releasesandpublications/er/Ir/liveregistermarch2020/ (accessed 2/4/2020).

Department of Health (2020a). 'Latest updates on Covid-19'. Government of Ireland. https://www.gov.ie/en/news/7e0924-latest-updates-on-covid-19-coronavirus/ (accessed 2/4/2020).

Department of Health (2020b). 'Previous updates on Covid-19'. Government of Ireland. https://www.gov.ie/en/publication/ce3fe8-previous-updates-on-covid-19coronavirus/ (accessed 2/4/2020).

Department of Employment Affairs and Social Protection (DEASP) (2020). 'Latest updates on Covid-19 from DEASP'. Government of Ireland. https://www.gov.ie/en/publication/66d22e-covid-19-deasp-information-foremployers-and-employees-pdf/ (accessed 2/4/2020).

Economic and Social Research Institute (2020). Quarterly Economic Commentary, Spring 2020.

Eichenbaum, M.S., S. Rebelo and M. Trabandt (2020). The macroeconomics of epidemics (No. w26882). National Bureau of Economic Research.

OECD, 2020. Evaluating the Initial Impact of COVID-19 containment measures on Economic Activity.

Sutherland, H. and F. Figari (2013). 'EUROMOD: the European Union tax-benefit microsimulation model', International Journal of Microsimulation, 6(1), 4-26.

World Health Organization (2020a). 'Coronavirus disease (COVID-2019) situation report $72^{\prime}$.

https://www.who.int/docs/default-source/coronaviruse/situationreports/20200401-sitrep-72-covid-19.pdf?sfvrsn=3dd8971b_2 (accessed $2 / 4 / 2020)$.

World Health Organization (2020b). 'Coronavirus disease (COVID-2019) situation report 37'. https://www.who.int/docs/default-source/coronaviruse/situationreports/20200226-sitrep-37-covid-19.pdf?sfvrsn=2146841e_2 (accessed 2/4/2020).

World Health Organization (2020c). 'Coronavirus disease (COVID-2019) situation report 10'. https://www.who.int/docs/default-source/coronaviruse/situationreports/20200130-sitrep-10-ncov.pdf?sfvrsn=d0b2e480_2 (accessed 2/4/2020). 


\section{APPENDIX A}

TABLE A.1 ASSUMED DISTRIBUTION OF UNEMPLOYMENT SHOCK, BY SECTOR

\begin{tabular}{|l|l|}
\hline Sector & Risk \\
\hline Agriculture, forestry \& fishing & Low \\
\hline Mining and quarrying, manufacturing, electricity, gas \& water supply & Medium \\
\hline Construction & High \\
\hline Wholesale \& retail & Medium \\
\hline Transport, storage & Medium \\
\hline Accommodation \& food service activities & High \\
\hline Information \& communication & Medium \\
\hline Financial \& insurance activities & Medium \\
\hline $\begin{array}{l}\text { Real estate, Professional, scientific \& technical, administrative \& } \\
\text { support service activities }\end{array}$ & Medium \\
\hline $\begin{array}{l}\text { Public administration and defence, compulsory social security } \\
\text { Education }\end{array}$ & Low \\
\hline Human health \& social work activities & Low \\
\hline $\begin{array}{l}\text { Arts, entertainment \& recreation, other service activities, activities as } \\
\text { household as employer }\end{array}$ & Low \\
\hline
\end{tabular}




\section{APPENDIX B: 'LOW' UNEMPLOYMENT SHOCK $(400,000)$}

\section{TABLE B.1 DIRECT EXCHEQUER COSTS, € MILLION PER QUARTER ('LOW' UNEMPLOYMENT SHOCK)}

\begin{tabular}{|l|r|r|r|r|}
\hline & \multicolumn{3}{|c|}{$€$ million per quarter } \\
\hline & \multicolumn{1}{|c|}{ A } & \multicolumn{1}{|c|}{ B } & \multicolumn{1}{c|}{ C } & \multicolumn{1}{|c|}{ D } \\
\hline Change in market income & $-\mathbf{4 , 3 8 4}$ & $-\mathbf{4 , 3 8 4}$ & $-\mathbf{4 , 0 0 8}$ & $-\mathbf{3 , 7 4 0}$ \\
\hline Change in personal tax revenue & -945 & -810 & -856 & -794 \\
\hline Change in employee SIC revenue & -157 & -157 & -157 & -157 \\
\hline Change in self-employed SIC revenue & -33 & -33 & -33 & -33 \\
\hline Change in employer SIC revenue & -381 & -381 & -381 & -379 \\
\hline Change in means-tested welfare expenditure & 45 & 56 & 63 & 41 \\
\hline Change in non means-tested welfare expenditure & 1,218 & 1,915 & 1,445 & 1,445 \\
\hline Cost of temporary wage subsidy & 0 & 0 & 379 & 379 \\
\hline Net Exchequer impact & $-\mathbf{2 , 7 7 8}$ & $-\mathbf{3 , 3 5 1}$ & $-\mathbf{3 , 3 1 4}$ & $-\mathbf{3 , 2 2 8}$ \\
\hline
\end{tabular}

Source: Own calculations using EUROMOD linked to 2017 EU-SILC data uprated to 2020 terms.

Notes: $\quad$ Calculations show the estimated quarterly cost of 'low' unemployment shock under four scenarios: A - no policy response; B - introduction of PUP and extension of fuel allowance; C - as B but around a quarter retained in employment through TWSS; $D-$ as $C$ but with additional payments by employers to maximum allowed under TWSS.

TABLE B.2 AVERAGE CHANGE IN DISPOSABLE INCOME, BY FAMILY TYPE ('LOW' UNEMPLOYMENT SHOCK)

\begin{tabular}{|l|c|c|c|c|c|}
\hline & \% of total & A \% & B \% & \multicolumn{1}{c|}{ C \% } & D \% \\
\hline Working age single without children & 28 & -10.0 & -5.5 & -5.8 & -4.8 \\
\hline Working age lone parent & 8 & -2.3 & -0.1 & -0.3 & -0.3 \\
\hline Working age couple without children & 15 & -10.3 & -7.5 & -7.7 & -6.5 \\
\hline Working age couple with children & 28 & -11.3 & -8.9 & -9.2 & -8.2 \\
\hline Single retirement age & 12 & -1.0 & 0.3 & 0.2 & 0.4 \\
\hline Couple retirement age & 9 & -2.4 & -0.7 & -0.9 & -0.7 \\
\hline
\end{tabular}

Source: Own calculations using EUROMOD linked to 2017 EU-SILC data uprated to 2020 terms.

Notes: Working age is defined as $18-65$. Children are aged under 18 . Retirement age is $66+$. Calculations show the average change in disposable income for different types of tax-unit due to a 'low' unemployment shock under four scenarios: A - no policy response; B - introduction of PUP and extension of fuel allowance; C - as B but around a quarter retained in employment through TWSS; $D-$ as $C$ but with additional payments by employers to maximum allowed under TWSS. 


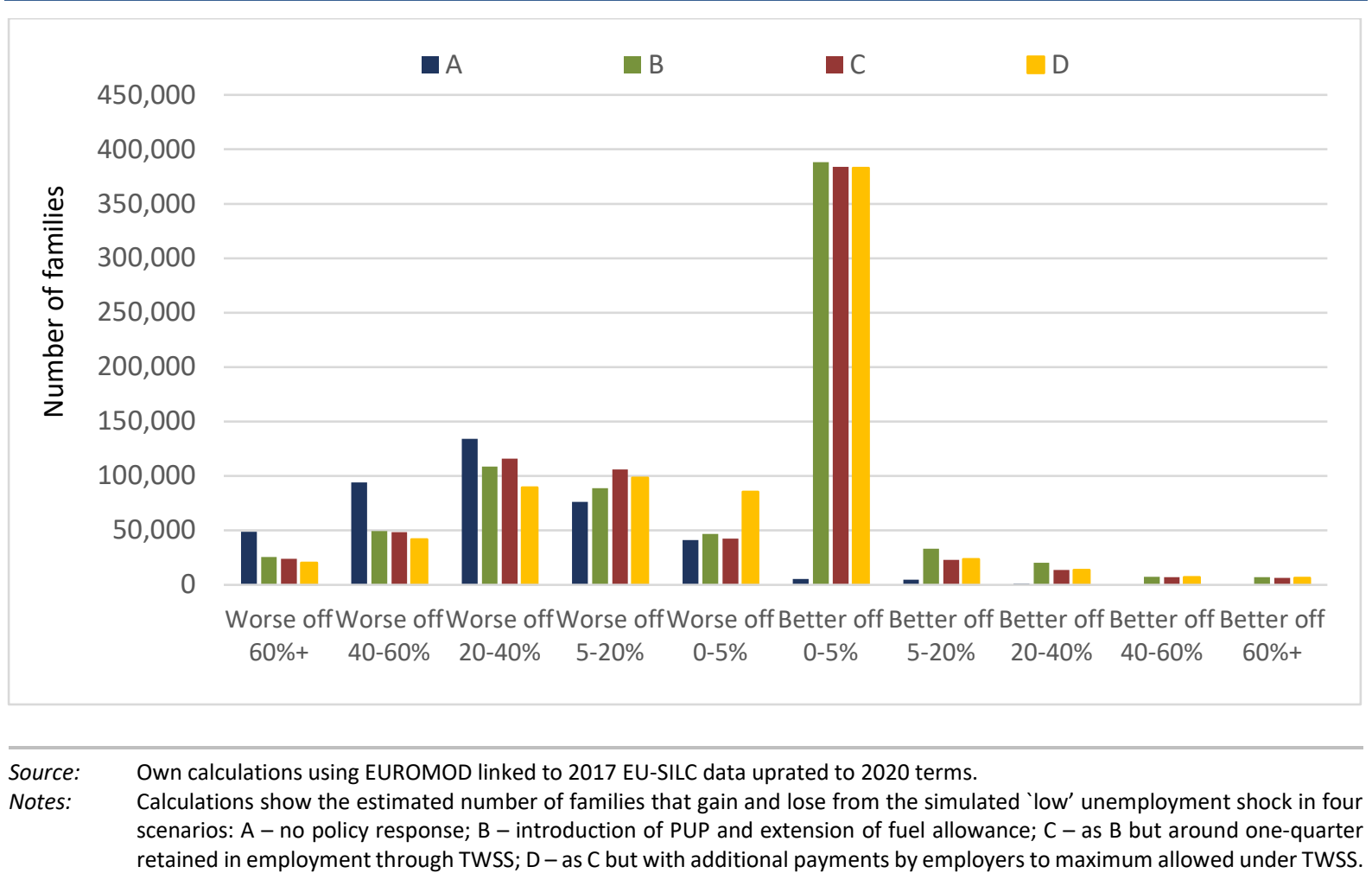

\section{FIGURE B.2 DISTRIBUTIONAL EFFECT OF 'LOW' UNEMPLOYMENT SHOCK}

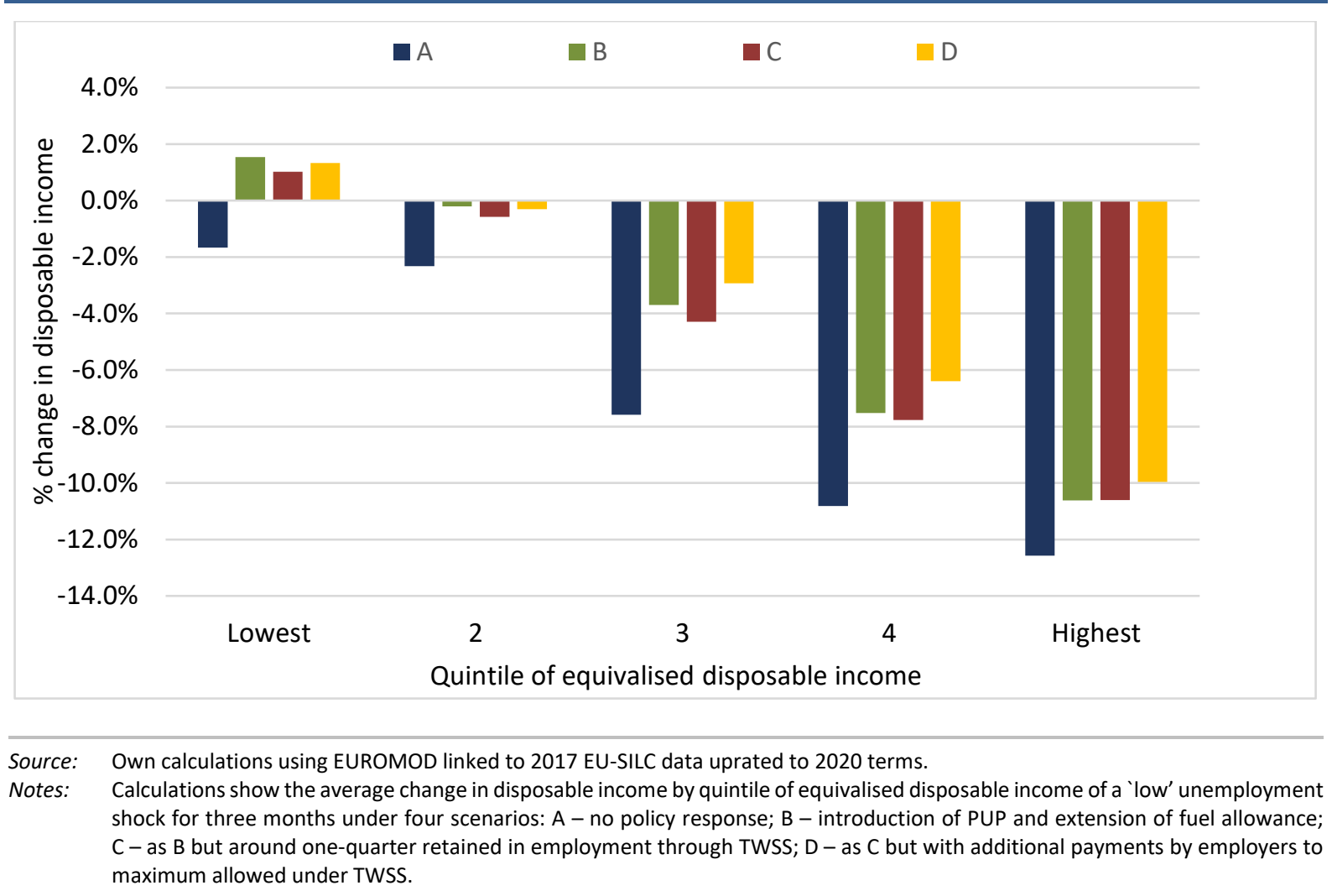




\section{APPENDIX C: ‘HIGH’ UNEMPLOYMENT SHOCK $(800,000)$}

\section{TABLE C.1 DIRECT EXCHEQUER COSTS, € MILLION PER QUARTER ('HIGH’ UNEMPLOYMENT SHOCK)}

\begin{tabular}{|l|r|r|r|r|}
\hline & \multicolumn{1}{|c|}{ A } & \multicolumn{1}{c|}{ B } & \multicolumn{1}{c|}{ D } \\
\hline Change in market income & $-8,341$ & $-8,341$ & $-6,474$ & $-5,178$ \\
\hline Change in personal tax revenue & $-1,716$ & $-1,476$ & $-1,712$ & $-1,416$ \\
\hline Change in employee SIC revenue & -315 & -315 & -315 & -315 \\
\hline Change in self-employed SIC revenue & -57 & -57 & -57 & -57 \\
\hline Change in employer SIC revenue & -736 & -736 & -736 & -730 \\
\hline Change in means-tested welfare expenditure & 86 & 94 & 143 & 44 \\
\hline Change in non means-tested welfare expenditure & 2,484 & 3,738 & 1,370 & 1,367 \\
\hline Cost of temporary wage subsidy & 0 & 0 & 1,883 & 1,883 \\
\hline Net Exchequer impact & $-5,394$ & $-6,416$ & $-6,217$ & $-5,811$ \\
\hline
\end{tabular}

Source: Own calculations using EUROMOD linked to 2017 EU-SILC data uprated to 2020 terms.

Note: $\quad$ Calculations show the estimated quarterly cost of 'high' unemployment shock under four scenarios: A - no policy response; B - introduction of PUP and extension of fuel allowance; C - as B but around 500,000 retained in employment through TWSS; $\mathrm{D}$ - as $\mathrm{C}$ but with additional payments by employers to maximum allowed under TWSS.

TABLE C.2 AVERAGE CHANGE IN DISPOSABLE INCOME, BY FAMILY TYPE ('HIGH' UNEMPLOYMENT SHOCK)

\begin{tabular}{|l|c|c|c|c|c|c|}
\hline & \% of total & A \% & B \% & C \% & D \% \\
\hline Working age single without children & 28 & -19.5 & -10.7 & -12.8 & -7.5 \\
\hline Working age lone parent & 8 & -6.9 & -1.3 & -4.7 & -1.8 \\
\hline Working age couple without children & 15 & -19.1 & -14.3 & -15.3 & -10.3 \\
\hline Working age couple with children & 28 & -19.9 & -16.0 & -17.2 & -12.6 \\
\hline Single retirement age & 12 & -2.6 & -0.4 & -0.1 & -0.2 & -1.2 \\
\hline Couple retirement age & 9 & -4.0 & -0.9 & -1.8 & & \\
\hline
\end{tabular}

Source: Own calculations using EUROMOD linked to 2017 EU-SILC data uprated to 2020 terms.

Note: Working age is defined as 18-65. Children are aged under 18 . Retirement age is $66+$. Calculations show the average change in disposable income for different types of tax-unit due to a 'high' unemployment shock under four scenarios: A - no policy response; $\mathrm{B}$ - introduction of PUP and extension of fuel allowance; C - as B but around 500,000 retained in employment through TWSS; D - as $C$ but with additional payments by employers to maximum allowed under TWSS. 


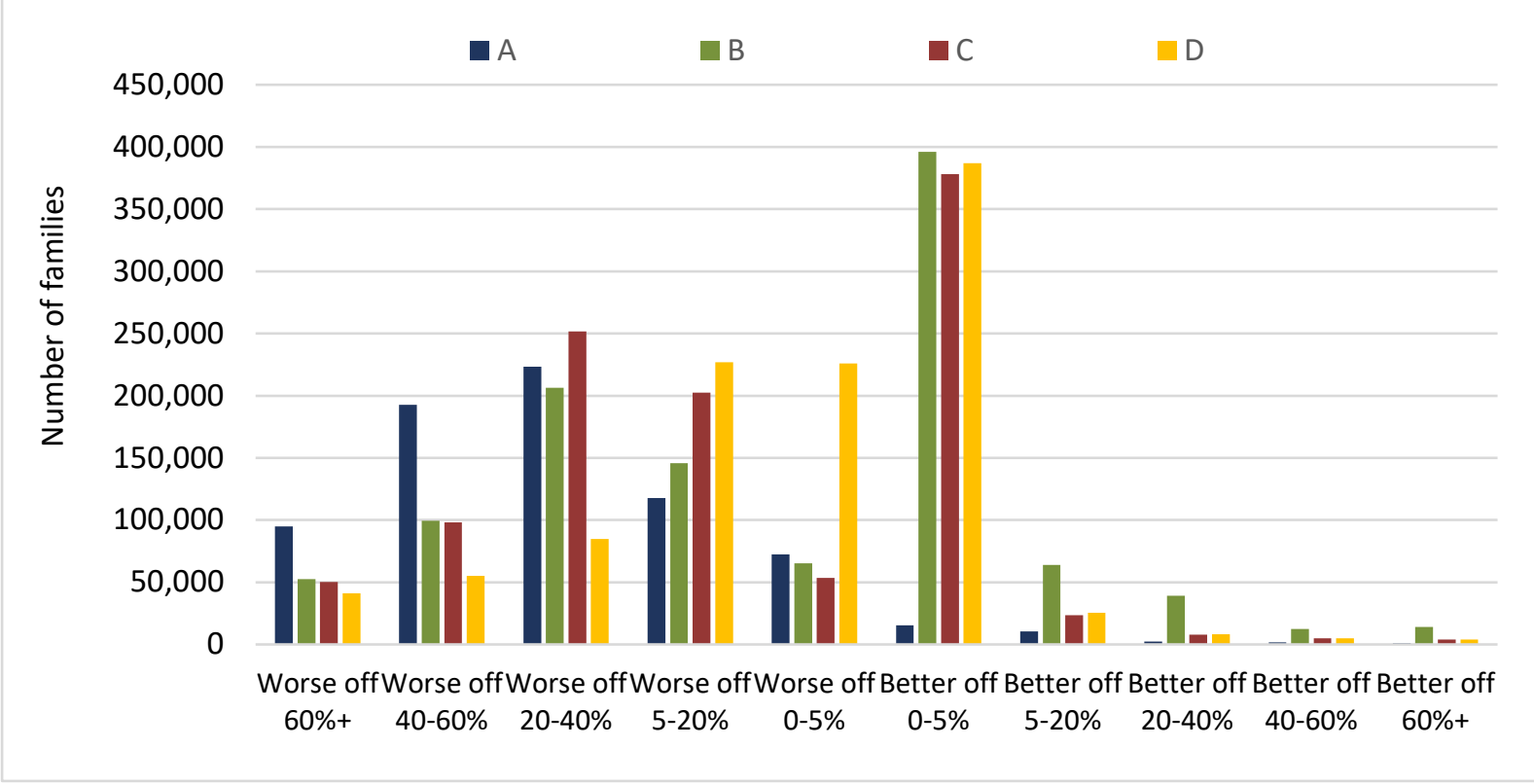

Source: Own calculations using EUROMOD linked to 2017 EU-SILC data uprated to 2020 terms.

Notes: $\quad$ Calculations show the estimated number of families that gain and lose from the simulated 'high' unemployment shock in four scenarios: A - no policy response; B - introduction of PUP and extension of fuel allowance; C - as B but around 500,000 retained in employment through TWSS; D - as C but with additional payments by employers to maximum allowed under TWSS.

\section{FIGURE C.2 DISTRIBUTIONAL EFFECT OF 'HIGH' UNEMPLOYMENT SHOCK}

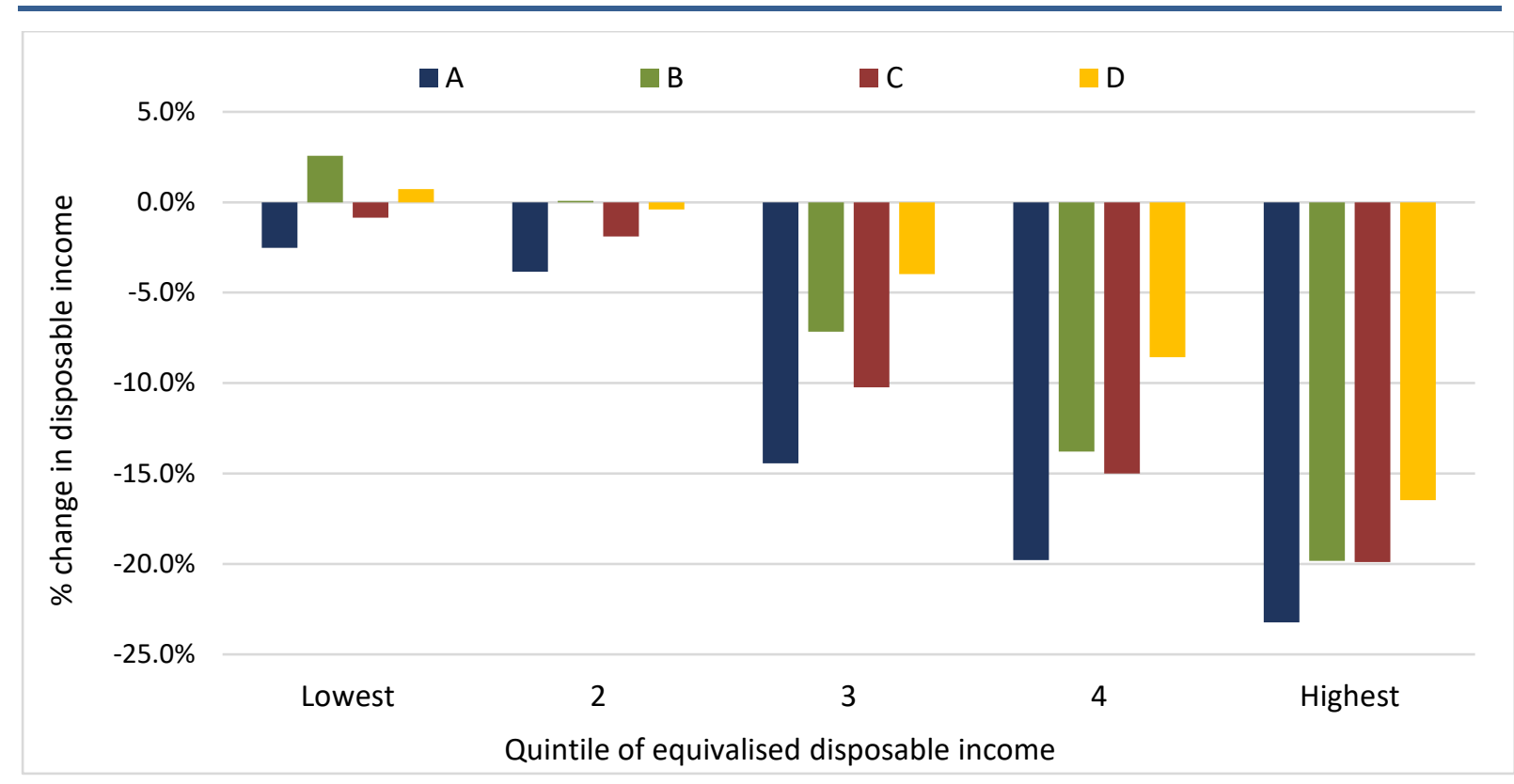

Source: Own calculations using EUROMOD linked to 2017 EU-SILC data uprated to 2020 terms.

Notes: Calculations show the average change in disposable income by quintile of equivalised disposable income of a 'high' unemployment shock for three months under four scenarios: A - no policy response; B - introduction of PUP and extension of fuel allowance; $C$ - as B but around 500,000 retained in employment through TWSS; D - as C but with additional payments by employers to maximum allowed under TWSS. 
Whitaker Square,

Sir John Rogerson's Quay,

Dublin 2

Telephone +35318632000

Email admin@esri.ie

Web www.esri.ie

Twitter @ESRIDublin 